Marquette University

e-Publications@Marquette

College of Communication Faculty Research and

Publications

Communication, College of

$1-1-2010$

\title{
Photojournalism: Historical Dimensions to Contemporary Debates
}

Bonnie Brennen

Marquette University, bonnie.brennen@marquette.edu

Published version. "Photojournalism: Historical Dimensions to Contemporary Debates," in The Routledge Companion to News and Journalism. Ed. Stuart Allan. New York: Taylor \& Francis (Routledge), 2010: 71-81. Publisher Link. (c) 2010 Taylor \& Francis (Routledge). Used with permission. 


\section{7 \\ PHOTOJOURNALISM: HISTORICAL DIMENSIONS TO CONTEMPORARY DEBATES Bonnie Brennen}

This chapter offers a brief discussion of the historical context surrounding recent discussions of photography and focuses on the role of photojournalism in contemporary society. As such, it addresses the introduction of photography and its perceived ability to provide authentic documentation of "reality" and details the development of photojournalism during the twentieth century. This chapter then focuses on challenges to the documentary role of photography since the introduction of digital technologies and notes the changing role of photojournalists showcasing their current emphasis on illustrating emotional aspects of experience.

\section{The pencil of nature}

Photographs are a way of imprisoning reality, understood as recalcitrant, inaccessible; of making it stand still (Sontag 1977:163).

The introduction of the daguerreotype in 1839 showcased the ability of the new medium of communication to accurately represent material aspects of society in a truthful, transparent, and authentic manner. First heralded as an "extraordinary triumph of modern science," (Poe 1840/1980: 37) the history of photography has presented photographs as news items, documentary evidence, objective renderings of reality, and individual works of art.

The word photography has Greek origins and literally means "writing with light." Initially, photographic images were thought to be devoid of human agency and formed solely through a chemical process dependent on "recording light-based 
information onto a reactive surface" (Newton 2001: 6). Soon after the development of the daguerreotype in the late 1830s, photographs began to shape not only the way individuals saw themselves but also the way they envisioned the world. Photographs were thought to verify the existence of a subject and offer a "triumph - of reality over illusion, of accuracy over art" (Adatto 2008: 42). Described as "the pencil of nature," photographs were presumed to provide objective proof that something actually happened and individuals began to believe that photographs could provide a "more accurate relation to visible reality" (Sontag 1977: 5) than other artistic renderings of society.

Given that photographs were created from the effects of light on film and lenses, they maintained a level of authenticity that could be considered to bypass human agency. C.S. Peirce refers to photographs as "indicies," direct pointers of reality that provide an assumed guarantee of being closer to the truth than other types of communication (Messaris and Abraham 2001: 217). Cameras were thought to produce photographs that were extraordinarily realistic, offering an authentic representation of things that actually existed; it was generally thought that the world could truly be seen and known through the transparent representations found in photographs (Walton 1984: 251). As John Berger explains: "What the camera does, and what the eye can never do, is to fix the appearance of that event. The camera saves a set of appearances from the otherwise inevitable supersession of further appearances. It holds them unchanging. And before the invention of the camera nothing could do this, except in the mind's eye, the faculty of memory" (Berger 1980: 14).

Because of their envisioned ability to represent an external reality, photographs have been thought to possess the power to authenticate evidence, to identify truth, and to expose deception. Throughout their history, photographs have been used to document news events, provide evidence of criminal activity, and to showcase scientific discoveries. For Roland Barthes, it is impossible to deny the existence of an image because "Photography's inimitable feature is that someone has seen the referent in flesh and blood, or again in person" (Barthes 1981: 79). In other words, if a horse is shown in a photograph, it is generally assumed that a horse must have been positioned in front of a camera, and did not merely exist in a photographer's imagination. The public's faith in the documentary aspect of photographs was so strong that, when confronted with an image of a horse, people not only believed that it existed but that the photograph depicted what the horse actually looked like. For many years, photographs were readily accepted as authentic representations of the real.

Photographers were first conceptualized as scribes, neutral observers who recorded an objective reality without any attempt at interpretation. The first photographers were not considered artists or authors but instead were known as camera operators. During the nineteenth century, photographers were generally treated as "technicians who initially received no credit or byline for the work they produced" (Schwartz 1999: 173). But soon it became clear that different people took different pictures, even when they were photographing the same thing, and the idea that cameras created an objective image soon began to give way to an understanding that photographs provide "evidence not only of what's there but of what an individual sees, not just a record but 
an evaluation of the world" (Sontag 1977: 88). Researchers began to demonstrate that the choice of a subject and the framing of that subject, as well as lighting decisions and camera angles, printing strategies, retouching, cropping, and labeling, all influenced the way an image would be interpreted; yet, in their daily usage photographs continued to be seen as truthful depictions of an objective reality. Photographs catered to the public's desire for facts and on newspapers and magazines, editors treated images as objective representations of the news, "reinforcing the professional ideology of objectivity and becoming the site of reality" (Hardt 2000: 63).

Although the camera continued to hold the promise of capturing realistic renderings of society, it was also a technology that could deceive, blurring the line between representation and reality. For example, Mathew Brady's collection of Civil War images represents the first time in the history of photography that a war was covered in its entirety. Brady and his team of photographers including Alexander Gardner, Timothy O'Sullivan, and George Barnard compiled approximately 7,000 images of Civil War battlefields and encampments. The "grim photographic images of the carnage left on the great battlegrounds of Antietam, Fredericksburg, Gettysburg, Spotsylvania, Cold Harbor, Petersburg, and Richmond" (Griffin 1999: 132) were initially thought to illustrate the reality of an extremely gruesome war. And yet, contemporary historians now maintain that the single most famous image in the Brady collection, "Home of a Rebel Sharpshooter," taken by Gardner with the assistance of O'Sullivan, was actually staged.

\section{The rise of photojournalism}

Images are bearers of meanings, enduring carriers of ideals and myths (Adatto 2008: 243).

The field of photojournalism is generally considered to address the presentation of news and information primarily through visual images. Documenting relevant social and political issues, at its best photojournalism may provoke engagement with written news reports and may question the status quo. And sometimes it may be seen to "capture art in real life" (Winslow 2006: 2). Yet, Michael Griffin suggests that the term photojournalism was "superimposed on the history of photography in hindsight" (Griffin 1999: 122); although the term was coined in response to the development of picture magazines established during the 1920s and 1930s, the concept of photojournalism has actually been used to showcase a variety of photographic practices that began in the 1830s.

While photojournalism came of age during the early twentieth century, combining documentary conventions with news, opinion, publicity, and propaganda, its history is often traced to the development of the daguerreotype in the late 1830s. Historians have determined that by 1846 news photography became a regular aspect of the work done by daguerreotypists. Between 1885 and 1910, an extensive number of photographs printed in newspapers and magazines helped lead to a "visual reorientation" among the American public, which seemed to offer them direct access to reality. At 
the end of the nineteenth century, the mass production of smaller and easy to use photographic equipment combined with the development of flexible film and faster dry plates helped to fuel the use of photography in advertising and journalism. And yet, the documentary promise contained in the halftone photographs "coexisted with the dangers of distortion, fabrication and simplification" (Newton 2001: 121).

During the early twentieth century, the publication of magazines such as Look and Life emphasized a documentary style of photography, showcasing journalistic objectivity, a search for social truths, and an affinity with the real. By the 1930s, documentary photography went beyond reproducing visions of everyday life, to describe key social and economic conditions shaping public views on immigration, poverty, and farm labor and aiding in the construction of an American national identity. Press photographers reflected contemporary values of newsworthiness, confirming or questioning "the facts" and offering "a visual gestalt of the news, information, and entertainment" (Hardt and Brennen 1999a: 5) that soon came to characterize the modern press.

In 1947, four photographers - Robert Capa, Henri Cartier-Bresson, George Rodger, and David "Chim" Seymour - founded the Magnum photo agency in an effort to combine artistry with an emphasis on interpretation. The photographers sought to showcase the poetry in the reality of life and they wanted the flexibility to choose their own stories and the amount of time they spent documenting them. Cartier-Bresson rejected the notion of photojournalists as neutral observers and insisted that, "photographers had to have a point of view in their imagery that transcended any formulaic recording of contemporary events" (Magnum Photos 2008). Generally considered the premier photographic agency, to this day Magnum supplies images to news media outlets, advertising agencies, galleries and museums throughout the world.

Throughout its history, the field of photojournalism has responded to pressures to provide aesthetically pleasing images along with authentic and truthful information about the world. As photographs began to provide objective news accounts, bolstering the authority of journalism, they acquired an aura of reality, truth, and objectivity documenting important events for readers. For example, photojournalists' realistic and graphic depictions of the liberation of the concentration camps confirmed journalistic reports and offered "irrefutable evidence of Nazi degradation and brutality" (Zelizer 1999: 106), while during the Vietnam War, photojournalists' graphic documentary images called into question official policy and were used as evidence to challenge the legitimacy of the war (Ritchin 1990).

Yet others began to focus on another aspect of photography - its ability to provide surveillance for powerful people in government, business, and science. As John Tagg explains: "Like the state, the camera is never neutral. The representations it produces are highly coded, and the power it wields is never its own. As a means of record, it arrives on the scene vested with a particular authority to arrest, picture and transform daily life; a power to see and record; a power of surveillance ..." (Tagg 1993: 63-4).

In the twenty-first century, while photographers still question how those with power might use or abuse their images, the focus on technical concerns regarding the construction of images seems less important than their ability to craft meaningful 
stories about important social concerns within their communities. As Paul Martin Lester explains, these days "A photojournalist is a mixture of a cool, detached professional and a sensitive, involved citizen. The taking of images is much more than f-stops, shutter speeds, white balances, and flak jackets" (Lester 2006: 144).

\section{Challenging the veracity of the image}

It seduces us by its proximity to the real and gives us the sensation of putting truth at our fingertips ... and then it throws a jug of cold water in our face (Meyer 1995: 7).

The development of new digital technologies near the end of the twentieth century signaled a series of challenges to the field of photojournalism. Questions were quickly raised about the authenticity of images, the responsibility for the content of photographs, and the role of photojournalists in contemporary society, which raised concerns that in the long run the new technologies might diminish the public's trust in journalism.

With digital imaging, elements of a photograph can easily be added, subtracted, and modified without detection. Critics invariably questioned the reliability of photographs to authentically document news and provide realistic information, and some began to wonder about the potential for digital images "to subvert reality" (Adatto 2008: 65).

Researchers and critics contend that because the manipulation of digital images can be impossible to detect, the new technology has compromised the perceived reliability, objectivity, and facticity of the photographic image. Given that photographers are now able to create images of things that do not exist, it is no longer possible to claim photography as an authentic "index of reality" (Mirzoeff 1999: 88). The Mexican poet Veronica Volkow suggests that because of the digital revolution, "the photograph breaks its loyalty with what is real, that unique marriage between the arts, only to fall into the infinite temptations of the imagination. It is now more the sister of fantasy and dreams than presence" (Volkow, in Meyer 1995: 78).

Digital images can be repositioned, reshaped or removed, blended with images from different sources, altered, deleted, or recorded over immediately or years later, which tends to lessen the authenticity of images because there is no longer an "equivalent to an original, archivally permanent negative" (Richin 1990: 65). In addition, there are fundamental differences between photographs and digital images particularly as it relates to the processes of enlargement and reproduction. The information in photographs is unending and the images can be continually enlarged to showcase greater detail. However, digital images can only be enlarged to a certain point, and beyond that point no additional information can be ascertained (Savedoff 1997: 210).

In digital imaging, "light is translated into a digital code read by a computer. Not only can that digital code be altered easily, but its alteration can be done in such a way as to be undetectable" (Newton 2001: 6). While the photographic process focuses on the recording of light, in the case of digital imaging, light is converted. Newton 
suggests that the words recorded and converted may help to explain the public's original trust in photography and their current distrust in digital imaging.

As William J. Mitchell notes, with digital imaging, "the referent has become unstuck" (Mitchell 1992: 31) and photographs no longer have the power to convince people that the evidence they provide is authentic and real. In his research, Mitchell draws on George Orwell's 1984, specifically referencing the novel's records department, which specialized in faking photographs. He suggests that with the development of personal computers, such a department is no longer necessary because now it is possible for anyone to fake photographs. Contemporary examples of digital abuse support Mitchell's concerns. For example, National Geographic's cover image of the pyramids of Giza was created by digitally moving the pyramids closer together so that the photograph would fit the magazine's vertical format. Newsweek combined separate images of Tom Cruise and Dustin Hoffman into what appears as an image of the two actors together; while the Los Angeles Times and its sister publications the Chicago Tribune and the Hartford Courant ran a front page news photograph of Iraqi citizens sitting on the ground, as an armed American soldier stands in the foreground which was actually a digital image created from two distinct photographs.

While digitally altered images currently "trade on the documentary aura" (Savedoff 1997: 213) of traditional photography, some fear that, as the digital manipulation of images becomes more widespread, all photography will lose its documentary function and the public will no longer consider it to represent the real. However, Mexican photographer Pedro Meyer challenges the public to avoid the hypocrisy associated with concerns over the manipulation of digital images, and he insists that "all photographs are manipulated" (Meyer 1995: 12). Meyer maintains that, through the choice of subject matter, the focus and framing of images, all photographers manipulate images. However, for Meyer, what is important to consider is the criteria or the intentions that are applied to the manipulation.

Some critics speculate that because of the inability to distinguish between an authentic image and one that has been electronically manipulated, in the future, media outlets will no longer use photographs to document events but will instead use photographs as illustrations. "Photographs will appear less like facts and more like factoids - as a kind of unsettled and unsettling hybrid imagery based not so much on observable reality and actual events as on the imagination" (Grundberg 1990: 1).

Yet others like New York Times reporter Andy Grundberg argue that photojournalism's loss of documentary authority may have more to do with the "superabundance and stereotypicality" (Grundberg 1990: 5) of images that populate the contemporary media landscape than with any specific challenges of digital imaging technology. Similarly, John Hartley suggests that photographs have become so ubiquitous and the media landscape now littered with images, that there is no longer much room for analysis or commentary (Hartley 2007: 556).

However, Kiku Adatto suggests that even with their ability to falsify information that the documentary power of the camera remains a significant feature in contemporary society. "We still want the camera to fulfill its documentary promise, to provide us with insight, and to be a record of our lives and the world around us" (Adatto 2008: 8). 
Adatto offers the example of the images of Abu Ghraib to illustrate the current documentary power of photographs and insists that without photographs there would have been no understanding of this issue and no investigation of the prison abuses.

Responding to concerns regarding the potential for the manipulation of digital imagery, newspaper executives have enacted strict guidelines against digitally altering news images and have disciplined photojournalists who have been caught changing images. Clearly maintaining a belief in the ability of photographs to document reality, in 1997 The Minneapolis Star Tribune suspended its photographer Stormi Greener, for digitally eliminating power lines from a photograph in violation of the newspaper's policy regarding the digital manipulation of images. It has been suggested that the newspaper's action of "publically excoriating Greener demonstrated to readers that the Star Tribune makes good on its claim to present only unmanipulated photographs" (Schwartz 1999: 159). More recently, in the 2003 example mentioned earlier, Los Angeles Times photographer Brian Walski was fired after the newspaper discovered that he had digitálly combined two images to create a new photograph of the Iraq War, while in 2006, Charlotte Observer photojournalist Patrick Schneider was also fired for digitally altering the color of the sky in a picture of a Charlotte firefighter. The newspaper reported that Schneider violated its photo policy, which states: "No colors will be altered from the original scene photographed" (Winslow 2006: 1).

In an effort to quell concerns regarding the potential to manipulate digital images as well as to strengthen public perception of photojournalism, the National Press Photographers Association (NPPA) recently updated its Code of Ethics. Affirming a primary goal of the "faithful and comprehensive depiction" of society, the ethics code warns photojournalists not to manipulate images and to avoid presenting their own "biases" in their work (NPPA 2008). John Long, chairperson of NPPA's Ethics and Standards Committee insists that all documentary news photographs are expected to be real and that if a news image looks real, "it better be real" (Long, quoted in Winslow 2006: 4).

\section{From documentary to emotional photojournalism}

Photography is subversive not when it frightens, repels, or even stigmatizes, but when it is pensive, when it thinks (Barthes 1981: 38)

By the mid-twentieth century, photojournalists were expected to provide technically perfect photographs, which were thought to portray an unbiased objective reality. For contemporary photojournalists, the emphasis is less on the physical process and photojournalists now focus on a more interpretive role, providing representations, persuasions, and understandings of larger issues in society.

Fred Richin suggests that new technologies have forced photojournalists to redefine their relationship to images; he urges photographers to stop overestimating the power of technology and to instead embrace the subjectivity of images. Ritchin draws on photographer Pedro Meyer's story of a nail on a wall to illustrate the capacity of photographs to engage in "subtle ambiguity, in soaring metaphor, in questioning the 
nature of reality rather than delineating conventional responses" (Ritchin 1990: 143). Meyer tells of a Peruvian experiment with Indian children who took pictures illustrating the concept of exploitation. One child took a picture of a nail on a wall. At first the instructors thought the child did not understand the assignment. However, they soon learned that a group of children lived in a poor town outside of Lima and each day they walked several miles into town to shine shoes. The children rented nails on a wall from a man who lived in town so that they did not have to carry the heavy shoeboxes back and forth each day. The man charged the children half of what they earned each day for rental of the nails. "As you can see, sometimes a picture of a nail on the wall means much more than just a nail on the wall" (Meyer, in Ritchin 1990: 100).

However, John Tagg warns that, although documentary photography has rejected the notion of objective evidence in favor of an emphasis on the emotion of experience, structures of power remain inscribed into photographic images. Tagg takes issue with the ways photojournalists position their subjects "as the 'feminised' Other, as passive but pathetic objects capable only of offering themselves up to a benevolent, transcendent gaze - the gaze of the camera and the gaze of the paternal state" (Tagg 1993: 12).

Because of their emotional power to entertain, educate, and persuade, media ethicists suggest that great care should be taken with all images that are published in order to insure that the representations do no harm. "The best reasons, ethically speaking, to show any news image are that it moves people to care and that it helps people to safely navigate through their daily lives" (Lester 2006: 141).

Photojournalist Marco Vernaschi suggests that contemporary photojournalism is shifting from an explicit documentary style to an emotional documentary style which goes beyond illustrating ideas and concepts found in news articles to help readers "feel the intensity of what they read" in journalistic reports (Vernaschi 2008). By visually representing emotions, documentary photographs present a specific world view and attempt to connect with the public on an intimate level encouraging the "sympathetic experience and action" of a diverse audience (Starrett 2003: 418). Contemporary photographs offer life stories of newsworthy individuals, illustrating their joy and pain, as well as their conflicts, challenges, and struggles, in an attempt to move readers on a personal and emotional level. Images that are not only aesthetically pleasing but also capture readers' attention emotionally are thought to help to foster understanding and create a sense of community (Rees 2004).

From this perspective, the photojournalist may be seen to inhabit the space of a "covert artist with an acute social conscience, intent on naming the nameless, revealing the contradictions of life, and exposing the emotions people would rather ignore or suppress beneath our supposedly rational culture" (Newton 2001: 50). As bell hooks suggests, readers' interpretations of photographs are based on their specific experiences and their emotional engagement with the images. Photographs can embrace, captivate, and seduce: "Such is the power of the photograph, of the image, that it can give back and take away, that it can bind" (hooks 1995: 56). 
Some photographic images offer such a strong emotional response or identification that they have reached iconic status and are reproduced and used within a variety of media to represent key historic events and issues. Lewis Hine's 1911 image "Breaker Boys," Dorothea Lange’s 1936 photograph "Migrant Mother," Joe Rosenthal's 1945 image, "Flag Raising on Iwo Jima," and Eddie Adams' 1968 photograph of the shooting of an alleged Vietnamese terrorist are all powerful ideological constructions that have contributed to widely accepted interpretations of history which have helped to build a socially constructed national identity (Hardt and Brennen 1999b: 15). More recently, the image of three Ground Zero firefighters standing on a pile of rubble and raising the American flag has "lodged in the public consciousness" (Franklin 2002: 64), becoming a powerful iconic image. Tom Franklin, the photographer who took the image, notes that his photograph has been reprinted extensively in the press and has been reproduced without authorization on plaques, figurines, coins, jewelry, T-shirts, Christmas tree ornaments, and country barns and used to represent Americans' courage, strength, and resilience following September 11.

According to Barbie Zelizer, after September 11, photography "rose to fill the space of chaos and confusion that journalism was expected to render orderly" (Zelizer 2002: 48). Images recycled in newspapers, news magazines, as well as in commemorative volumes became an integral aspect of journalism, creating a realm of contemplation within the documentary record, helping citizens to bear witness to the events, and providing public support for future political and military activities. The recycling of September 11 images also served in a phenomenological role, providing realistic representations and also mementos of the actual experience for people to purchase, save, share, critique, and revisit (Anden-Papadopoulus 2003: 102). Iconic photographs that are infused with memory and history may ultimately provide representations of historically based "truths" that help to create a socially constructed collective identity in contemporary societies.

Finally, in a media saturated environment when everyone who owns a cell phone may be considered a member of the press, and when any image may be posted on line and become a part of the public record, it seems important to consider, who is a photojournalist?

In 2009, newspapers and magazines employ a limited number of staff photographers - the majority of the images used now come from freelance photographers, photo-agencies like Magnum, and archives. Media outlets are provided with a large number of images from which they are able to select, revise, and change the photographs at will. Such a system provides editors with the images they desire as well as a great degree of visual flexibility, without the need to "maintain a waged workforce of photojournalists" (Hartley 2007: 557). The emphasis on freelance photographers has helped to reduce the power of photojournalists who, in one sense, may now be seen as "a vulnerable and often passive cog in a well-oiled machine" (Ritchin 1990: 110).

While photographs may be seen as visual constructions of a social reality, it may be particularly important to heed John Hartley's warning that, in late industrial capitalist societies, "the democratization and monetization of photojournalism has reached its logical conclusion: now we're all paparazzi" (Hartley 2007: 561). 


\section{References}

Adatto, K. (2008) Picture Perfect. Life in the Age of the Photo Op. Princeton: Princeton University Press.

Anden-Papadopoulus, K. (2003) "The Trauma of Representation. Visual Culture, Photojournalism and the September 11 Terrorist Attack," Nordicom Review, 24: 89-104.

Barthes, R. (1981) Camera Lucida. Reflections on Photography. New York: Hill and Wang.

Berger, J. (1980) About Looking. New York: Pantheon Books.

Franklin, T. (2002) "The After-Life of a Photo That Touched a Nation," Columbia Journalism Review, March/April: 64-5.

Griffin, M. (1999) “The Great War Photographs," pp. 122-57, in B. Brennen and H. Hardt, (eds.) Picturing the Past. Media, History and Photography, Urbana: University of Illinois Press.

Grundberg, A. (1990) "Photography View; Ask It No Questions: The Camera Can Lie," New York Times. Online. Available: http://query.nytimes.com/gst/fullpage.html?res=9C0CE7DC163CF931A2575BC0 A966958260 (accessed 17 October 2008).

Hardt, H. (2000) In the Company of Media. Cultural Constructions of Communication, 1920s-1930s. Boulder, CO: Westview.

Hardt, H. and Brennen, B. (1999a) "Introduction," pp. 1-10, in B. Brennen and H. Hardt, (eds.) Picturing the Past. Media, History and Photography, Urbana: University of Illinois Press.

Hardt, H. and Brennen, B. (1999b) "Newswork, History, and Photographic Evidence: A Visual Analysis of a 1930s Newsroom," pp. 11-35, in B. Brennen and H. Hardt (eds.) Picturing the Past. Media, History and Photography, Urbana: University of Illinois Press.

Hartley, J. (2007) "Documenting Kate Moss. Fashion Photography and the Persistence of Photojournalism," Journalism Studies, 8: 555-65.

hooks, b. (1995) Art On My Mind. Visual Politics. New York: New Press.

Lester, P.M. (2006) "On Mentors, Ethics, and Weapons," Visual Communication Quarterly, 12: 136-45.

Magnum Photos. (2008) "History of Magnum," Online. Available: http://agency.magnumphotos.com/ print/node/50 (accessed 4 September 2008).

Messaris, P. and Abraham, L. (2001) "The Role of Images in Framing News Stories," pp. 215-26, in S. Reese, O. Gandy, Jr., and A. Grant (eds.) Framing Public Life: Perspectives on Media and Our Understanding of the Social World, Mahwah, NJ: Erlbaum.

Meyer, P. (1995) Truths and Fictions: A Journey from Documentary to Digital Photography. New York: Aperture.

Mirzoeff, N. (1999) An Introduction to Visual Culture. London: Routledge.

Mitchell, W.J. (1992) The Reconfigured Eye. Visual Truth in the Post-Photographic Era. Cambridge, MA: The MIT Press.

NPPA Code of Ethics (2008). Online. Available: http://www.nppa.org/professional_development/ business_practices/ethics/html (accessed 2 October 2008).

Newton, J.H. (2001) The Burden of Visual Truth. The Role of Photojournalism in Mediating Reality. Mahwah, NJ: Erlbaum.

Poe, E.A. (1840/1980) “The Daguerreotype," pp. 37-38, in A. Trachtenberg, (ed.) Classic Essays on Photography. New Haven, CN: Leete's Island Books.

Rees, D. (2004) "Picturing a Free Press. Photographs Have the Power to Bring the Truth to Life," IPI Global Journalist, 3rd quarter: 16.

Ritchin, F. (1990) In Our Own Image. The Coming Revolution in Photography. New York, Aperture.

Savedoff, B. (1997) "Escaping Reality: Digital Imagery and the Resources of Photography," The Journal of Aesthetics and Art Criticism, 55: 201-14.

Schwartz, D. (1999) "Objective Representation: Photographs as Facts," pp. 158-81, in B. Brennen and H. Hardt (eds.) Picturing the Past. Media, History and Photography, Urbana: University of Illinois Press

Sontag, S. (1977) On Photography. New York: Farrar, Straus and Giroux.

Starrett, G. (2003) "Violence and the Rhetoric of Images," Cultural Anthropology, 18: 398-428.

Tagg, J. (1993) The Burden of Representation. Essays on Photographies and Histories. Minneapolis: University of Minnesota Press.

Vernaschi, M. (2008) "An Interview With Photojournalist Marco Vernaschi." Online. Available: $<$ http://www.magicalplacesfineart.com/blog/2007/10/an-interview-with-photojournalist-marcovernaschi/ (accessed 3 October 2008). 
Walton, K.L. (1984) "Transparent Pictures: On the Nature of Photographic Realism," Critical Inquiry, 11: 246-77.

Winslow, D.R. (2006) "A Question of Truth: Photojournalism and Visual Ethics," National Press Photographers Association. Online. Available: http://www.nppa.org/news_and_events/news/2006/08/ ethics.html (accessed 12 October 2008).

Zelizer, B. (2002) "Photography, Journalism, and Trauma," pp. 48-68, in B. Zelizer and S. Allan (eds.) Journalism After September 11, London: Routledge.

Zelizer, B. (1999). "From the Image of Record to the Image of Memory: Holocaust Photography Then and Now," pp. 98-121, in B. Brennen and H. Hardt (eds.) Picturing the Past. Media, History and Photography, Urbana: University of Illinois Press. 